\title{
Editorial
}

\section{Unlocking potential: challenges for primary health care researchers in the prison setting}

This issue of Primary Health Care Research and Development features a number of papers concerned with researching the needs of, and services for, socially excluded groups. Many prisoners have experienced social exclusion including running away from home as a child, truanting and exclusion from school, poor numeracy and reading skills, unemployment, and homelessness. The social disadvantage that many prisoners experience also affects their families, particularly children, as well as the community from which they originate.

Research into many aspects of primary care involving prisoners is lacking. In many countries, the concept of primary care in prisons is new, with the focus of health care being on mental health and substance misuse, and in some areas communicable diseases where there is a large public health issue. It is understandable that the research evidence will be thin in new and emerging areas of primary care such as in the prison setting, and many opportunities exist for researchers to develop our knowledge and understanding of a very needy population.

The United States of America has the highest imprisonment rate in the world at 724 per 100000 of the population with the Russian Federation next at 574 per 100000 of the population; the rate of imprisonment for England and Wales although much lower than the USA or Russian Federation, is significantly higher than most other Western European countries at 140 per 100000 population (International Centre for Prison Studies, 2006). Prison health care varies enormously across the world with some countries providing services similar to those provided to the general population and others only providing remedial health services. Good prison health care is important to the wider public health agenda, and the World Health Organization (WHO) is leading on a number of interesting projects in prisons related to mental health, communicable diseases, drugs, and in Europe the Health in Prisons Project (HiPP) (WHO, 2006a).

The establishment in England and Wales of a formal partnership between the prison service and the National Health Service (NHS) in 1999 (Joint Prison Service and NHS Executive Working Group, 1999) followed long standing concerns about the standards of health care in prisons, and variability in the organization and delivery of prison health services (HMIP, 1996). The partnership provides an opportunity for service providers to develop services in line with UK Government's modernization agenda with a commitment to provide health services to prisoners' equivalent to that in the wider community. The provision of health care in prisons in England is currently reaching an important stage in these reforms, with the transfer of management of prison health care services from the Prison Service to the NHS being completed by April 2006. Strategic Health Authorities will pass funding for prison health care to Primary Care Trusts (PCT) and it is expected that PCTs will have full control by April 2006.

The reorganization of prison health care is intended to improve services by enabling prisoners to have access to the same quality and range of NHS health services as the general public. Health needs assessments (Department of Health/HM Prison Service, 2002) undertaken by each prison together with their local health organizations, form the basis for planning and commissioning services. Baseline standards (Department of Health, 2004a; 2004b) include a commitment to provide access to a primary care professional within 24 hours and to a primary care doctor within 48 hours. The Prisons Inspectorate have argued that the reorganization of prison health care in addition to providing equivalent health care, could bring some important benefits such as better skill mix among staff, more effective management, 
a 'health needs' driven service, and greater patient empowerment (HMIP, 2004).

There are currently 85 PCTs that have at least one prison in their area, and all but one Strategic Health Authority in England has at least one prison in their sphere of responsibility. A national programme of work commenced in 2000 to support the modernization of the prison health service, and test models of service delivery and developing clinical services, the workforce, and performance management (Health Services Management Centre, 2004).

At any one time there are around 74000 people held in 140 prisons in England and Wales with an annual turnover of around 130000 offenders (House of Lords and House of Commons Joint Committee on Human Rights, 2004). The rate of imprisonment at 142 per 100000 of the population is higher than any other European country and the number of women in prison has nearly trebled in the past three decades (Prison Reform Trust, 2005). The recent rise in the prison population is due to larger numbers of offenders being sent to prison and longer sentences. Magistrate's courts are three times more likely to send offenders to prison compared to 10 years ago, and in the Crown Court, almost twice as likely. First time burglars are almost twice as likely to receive a custodial sentence as eight years ago (Carter, 2003). The numbers of offenders receiving shorter sentences has also increased by nearly double in the past 10 years, and now nearly half of prisoners have prison terms for six months or less (Home Office, 2003). In May 2005 there were 76033 people in prison including 4496 women and 10640 young people under 21. One in four prisoners were from a minority ethnic group compared to one in eleven of the general population (Prison Reform Trust, 2005) and imprisonment is considerably more likely for black men than for white men, although less so for South Asian men (Coid et al., 2002). Twenty-nine per cent of women in prison are from minority ethnic backgrounds (Prison Reform Trust, 2005).

Prison is not a healthy place and in general, prisoners are not healthy people and are vulnerable when they enter prison. Mental health, including self-harm, substance abuse, and alcohol related problems are major concerns within prisons. Levels of mental health disorders are much higher than in the general population with $72 \%$ of male, $70 \%$ of female, and $95 \%$ of young prisoners (15-21 years) with these problems (Social Exclusion Unit, 2002).
Twenty per cent of male and fifteen per cent of female prisoners have previously been admitted to a mental hospital before coming into prison, and according to MIND (National Association for Mental Health), 'Prison appears to be a good greenhouse for developing mental health problems' (House of Lords and House of Commons Joint Committee on Human Rights, 2004).

Around $40-55 \%$ of new receptions into prisons are problematic drug misusers, with some prisons estimating as many as $80 \%$ of arrivals testing positive to opiates and evidence that drug misusers are more vulnerable to self-harm and suicide (House of Lords and House of Commons Joint Committee on Human Rights, 2004). Alcohol addiction is often overlooked in prisons, yet is also seen to be a significant cause of distress that can lead to suicide and self-harm (House of Lords and House of Commons Joint Committee on Human Rights, 2004). The suicide rate is falling in the general population however in prisons it is rising (HMIP, 2004; House of Lords and House of Commons Joint Committee on Human Rights, 2004) with around two people committing suicide per week with most of these being males in the 30-39 age group. There are a disproportionate number of females and white prisoners committing suicide.

Communicable diseases are common amongst prisoners. Human immunodeficiency virus (HIV) infection of male prisoners is 15 times higher and female prisoners have Hepatitis B 40 times higher and Hepatitis C 28 times higher than in the general population (Social Exclusion Unit, 2002). This is partly due to the high number of prisoners who have injected drugs, and although no reliable data is available, may also be partly due to prisoners engaging in homosexual activity (House of Lords and House of Commons Joint Committee on Human Rights, 2004). Tuberculosis affects the most vulnerable such as the homeless, the poor, and newly arrived immigrants; all of whom are represented in the prison population (WHO, 2006b). Tuberculosis rates in prisons are many times higher than the general population, and prisons act as a 'reservoir' of tuberculosis that threatens many (WHO, 2006b).

The effects of the prison environment on prisoners' health cannot be overestimated. Overcrowding is a problem with more than half of all prisons in England and Wales being overcrowded in the past year (Prison Reform Trust, 2005) with some prisoners spending 23 hours a day in a shared cell 
with an unscreened toilet (HMIP, 2004). Prisoners experience anger, frustration, and anxiety (Nurse et al., 2003) and a worsening of health problems such as sleep disturbance, fatigue, and depression (Birmingham, 2003). Lack of autonomy in meeting personal health needs, isolation, and the lack of fresh air (Sim, 2002) also add stress, along with threatening behaviour by other prisoners and worries about home and family (Lester et al., 2003). Many events during a prisoner's day can also have a detrimental effect on their health. Situations such as court appearances, sentencing at court, returning from home visits, questioning by the police, bad or missed visits, bad telephone conversations, upsetting letters, and the death of another prisoner can be damaging to already vulnerable people.

Recent searches and reviews of primary care in prisons have identified a lack of research in a number of areas. For example, a Medline search on primary health care and public health in prisons conducted on behalf of the Prison Health Research Network (PHRN, 2006) found very little research on older people in prison, and research about aspects of health care such as diabetes, smoking, and health promotion was limited. Whilst in prison prisoners use the health services on offer and more frequently than an equivalent general population, which is understandable in a closed environment. However there is limited research as to the most appropriate services to provide, who is the most appropriate person to provide them, how services should be provided, and whether they are effective. There is also very limited research exploring why prisoners use primary health care services and the effect of the prison environment on healthseeking behaviour, and in a general sense, the prisoners' voice is missing in much of the published research (Hek et al., 2005). There is a dearth of research into the roles of primary health care staff working in prisons such as general practitioners, pharmacists, and nurses including clinical roles; collaborative working with other health care teams such as mental health in-reach and substance misuse teams; and models of service provision. Some aspects of prisoners' health care such as substance misuse and detoxification programmes, and hepatitis B immunization initiatives have received financial investment in the past two or three years (Condon et al., 2006) and these need evaluation at both national and local levels.
Prisoners are a vulnerable and needy population in terms of health; however some aspects of health need are poorly researched in this population, particularly general health. With the recent changes in health service provision for prisons in England, research is needed in all aspects of primary care in prison from effectiveness studies to qualitative research, impact studies on the transfer of services to research about information technology in prison, comparative studies with other populations, and in-depth research with specific vulnerable groups.

Gill Hek
Reader in Nursing Research,
Faculty of Health and Social Care,
University of the West of England,
Glenside, Blackberry Hill,
Stapleton,
Bristol,
BS16 1DD,
UK

\section{Acknowledgements}

Gill Hek and colleagues from the University of the West of England in Bristol are currently completing a national Department of Health funded research project looking at primary care nursing in prisons.

\section{References}

Birmingham, L. 2003: The mental health of prisoners. Advances in Psychiatric Treatment 9, 191-201.

Carter, P. 2003: Managing offenders, reducing crime. London: Strategy Unit.

Coid, J., Petruckevitch, A., Bebbington, P., Brugha, T., Bhugra, D., Jenkins, R., Farrell, M., Lewis, G. and Singleton, N. 2002: Ethnic differences in prisoners. 1: Criminality and psychiatric morbidity. British Journal of Psychiatry 181, 473-80.

Condon, L., Hek, G. and Harris, F. 2006: Public health, health promotion and the health of people in prison. Community Practitioner 79, 19-22.

Department of Health. 2004a: Standards for better health. London: Department of Health.

Department of Health. 2004b: National standards, local action. London: Department of Health.

Department of Health/HM Prison Service. 2002: Developing and modernising primary care in prisons. London: Department of Health. 
Health Services Management Centre. 2004: Sign posting to prison health. Birmingham: University of Birmingham.

Hek, G., Condon, L. and Harris, F. 2005: Primary care nursing in prisons: a systematic overview of policy and research literature. Bristol: University of the West of England. Retrieved 31 March 2006 from, http://www.phrn.nhs.uk/ workstreams/primarycare/

HM Inspectorate of Prisons for England and Wales. 1996: Patient or prisoner? A new strategy for health care in prisons. London: Department of Health.

HM Inspectorate of Prisons for England and Wales. 2004: Annual report of HM Chief Inspector of prisons for England and Wales 2002-2003. London: The Stationery Office.

Home Office. 2003: Prison statistics England and Wales 2002. London: The Stationery Office.

House of Lords and House of Commons Joint Committee on Human Rights. 2004: Deaths in custody: third report of session 2004-5 volume 1. London: The Stationery Office.

International Centre for Prison Studies. 2006: Prison population rates per 100,000 of the national population. Retrieved 2 February 2006 from, http://www/kcl.ac.uk/depsta/rel/icps/ worldbrief/highest_to_lowest_rates.php

Joint Prison Service and National Health Service Executive Working Group. 1999: The future organisation of prison health care. London: Department of Health.
Lester, C., Hamilton-Kirkwood, L. and Jones, N.K. 2003: Health indicators in a prison population: asking prisoners. Health Education Journal 62, 341-49.

Nurse, J., Woodcock, P. and Ormsby, J. 2003: Influence of environmental factors on mental health within prisons: focus group study. British Medical Journal 327, 480.

Prison Health Research Network. 2006: Primary health care bibliography. Retrieved 31 March 2006 from, http:www.phrn. nhs.uk/workstreams/primarycare/

Prison Reform Trust. 2005: Prison reform trust factfile. London: The Stationery Office.

Sim, J. 2002: The future of prison health care: a critical analysis. Critical Social Policy 22, 300-23.

Social Exclusion Unit. 2002: Reducing re-offending by exprisoners. London: Social Exclusion Unit.

World Health Organisation. 2006a: WHO Health in Prisons Project. Retrieved 8 March 2006 from, http://www.euro.who. int/prisons

World Health Organisation. 2006b: World Health Organisation: communicable diseases, tuberculosis. Retrieved 2 February 2006 from, http://W3.whosea.org/en/Section10/Section2097/ Section2106-10684.htm 